\title{
Education as the basis for the career development
}

\author{
Marta Matulcikova ${ }^{1}$, Anna Hamranova ${ }^{2 *}$, Tatiana Hrivikova ${ }^{3}$ \\ ${ }^{1}$ University of Economics in Bratislava, Faculty of Business Management, Department of \\ Management, Dolnozemska 1, 85235 Bratislava, Slovakia \\ ${ }^{2}$ University of Economics in Bratislava, Faculty of Business Management, Department of Information \\ Management, Dolnozemska 1, 85235 Bratislava, Slovakia \\ ${ }^{3}$ University of Economics in Bratislava, Faculty of Applied Languages, Department of Intercultural \\ Communication, Dolnozemska 1, 85235 Bratislava, Slovakia
}

\begin{abstract}
A career can be seen as a sequence of employments, jobs and positions an individual fills in throughout their professional life. The choices made within the educational system seem to influence its successful start. The formal educational system is nowadays a preparatory stage for both professional life and lifelong learning. Retaining one's employment and career development goes, therefore, hand in hand with lifelong learning while employers play a significant role in all forms of further professional development. Our purpose for this paper is to analyse the transition from education to employment and subsequent lifelong learning. The paper aims to assess the importance of the achieved educational level in further career development and the attitude of Slovak companies towards further training and development. Another aim is to formulate proposals and improvements for a successful transition to the professional sphere, as well as progress in the preparation for a career and lifelong employment. We used standard methods of scientific research such as analysis, synthesis, comparison, and selection, but a questionnaire survey was used as our major research method. To evaluate the results, descriptive statistical methods were implemented together with pivot tables. Eventually, we verified our hypotheses by statistical methods and coefficients appropriate for the evaluation of associations between nominal or dichotomic parameters: chi-square and Cramer's V. For validation, PSPP statistical software was implemented.
\end{abstract}

\section{Introduction}

Career represents a lifelong process of self-creation, it begins with decisions about the field of formal education, constant improvement of one's potential and its adaptation to the dynamic conditions of the labour market. The requirements related to work performance grow ever higher and the intellectualisation of work requires constant improvements in qualification [1-2]. The qualification background needed for work performance is constantly changing, it is influenced by the necessity of permanent innovations in

\footnotetext{
* Corresponding author: anna.hamranova@euba.sk
} 
production and services, the use of new technologies and above all, by the advancement of information and communication technologies [3-6]. All educational activities need to adapt to these trends:

- In the formal, i.e., primary, secondary, and tertiary education as part of school curricula, but also in further education [7-8], that is intended for individuals preparing for their profession within the framework of informal education which supplements the formal system.

- In adult vocational education which creates conditions for formal adult education within the framework of the school system leading to higher qualification with formal credentials of qualification. During that period of life, further adult vocational training is central [8] as it is closely related to work performance and accompanies one's career development. This includes:

$\circ$ Adaptive training.

- Further qualification development focused on professional growth and improvement of one's existing qualification [9]:

- Innovative education and qualification refreshment

- Extending and deepening the achieved qualification.

- Requalification - change of profession [9]:

- Requalification in a related field - it can take the form of formal or informal requalification (more often the result of informal education).

- Targeted requalification - change of existing qualification by acquiring knowledge, skills, and habits necessary for a new profession, usually aimed at a specific new working position. It is often acquired within the formal educational system.

The choice of formal education (secondary and tertiary ones) and their successful completion conclude the preparatory phase for a career. Completing the preparatory phase has an impact on the beginning of the first employment. We can often witness very difficult transitions from school to real working life or even move from formal education to unemployment which is an alarming fact requiring due attention. But we did not deal with it in our paper, as we included only those respondents into our sample who were at that time employed. The next relevant group consists of those who do not work in their area of study. This leads to the amortisation of finances invested into their education by society. All these factors had an impact on our empirical analyses. We collected information provided by experts and specialists in the area who explain the reasons for the existing discrepancy between education and subsequent employment. Their opinions - results of fundamental and empirical research can be characterised as follows:

- Personal perception of an individual: motivation, needs, faculties, talent, preferred values, willpower, intellect, emotional intelligence etc. [10-11].

- Attitudes of legal guardians (parents), their judgement of the aspirations and motivation for education and subsequent career prospects [12-14], considerations of performance, motivational characteristics, dynamic properties etc.

- Interpretation of an individual's personality by educational counsellors [15], Interpretation of an individual's personality by career counsellors [16-17], Interpretation of an individual's personality by human resources specialists [18-19].

In the context of the Slovak Republic, the decision-making power about one's education lies in the hands of the individual willing to study and his/her legal guardians. Unfortunately, the choice of an educational institution is often random, based on the 
opinions of parents, relatives and acquaintances and it does not take into consideration the personality of the individual who is being steered towards a particular career. Frequently, some extreme approaches can be registered when a school is chosen because of its social prestige or conversely, it is easy to pass. It is often overlooked that formal education takes time, and the graduates enter the labour market with a few years delay. Therefore, the choice of school should reflect the presumed conditions and employment prospects for the near future when the student graduates in the specific field of study. It is important to consider the number of graduates in various branches that the national economy is capable to employ. This requires the involvement of educational and career counsellors, specialists who are familiar with the trends in various professions on the labour market. This could create favourable conditions for future career success [20-21]. This way, situations could be eliminated when a graduate cannot find a job, becomes unemployed, needs to requalify, or works in a different field.

Dynamic conditions of the labour market, emergence of new and disappearance of some previous professions and the increasing demands for high work performance turn the attention to education as a central prerequisite for lifelong employment [22]. Therefore, formal education is currently more a preparatory phase for lifelong learning rather than just for one's professional life.

\section{Research Framework and Methods}

The main aim of the paper is to study the importance of the achieved qualification for career development and the approach of various companies operating in Slovakia towards further education. Based on a questionnaire survey, identify the problems in placing employees into the working process according to their qualification and assess the interest for and the scope of further education. The paper intends to interpret the results in a wider context. We wish to point out the practical needs from the employers' perspective which should initiate changes in formal education. We assume that if the education system is expected to become more adapted to the requirements of the professional sphere it needs to increase the cooperation with the entrepreneurial sphere.

The research consisted of three main stages. In the first stage, we focused on the study of scientific publications dealing with two important topics; the importance of achieved qualification for entering the labour market and further education and training in companies operating in Slovakia.

During the second stage, we formulated our research assumptions and research hypotheses. Simultaneously, a research model was created (model of research indicators) for the validation of the hypotheses. Table 2 shows the research model with the partial results.

The third stage included the statistical verification of the hypotheses and the formulation of conclusions. Adaptation of education at all levels to the requirements of economic practice reflects the future vision of the society.

\subsection{Research assumptions and research hypotheses}

We specified the following assumptions for the research:

1 Individuals with higher education are more easily placed in the working process according to their education and they are more interested in further education or training in comparison with people with a lower level of education.

2. Large enterprises pay more attention to achieving accord between employee placement and their qualification and are more interested in further training than small and middlesized companies. 
3. The sectors of the economy in which a company operates has no impact on employee placement neither on their access to further education.

4. Individuals working in managerial positions are more interested in further education than people working in non-managerial positions.

To validate the research assumptions, four sets of research hypotheses were formulated as the null and alternative hypothesis.

1. Set of hypotheses:

$1 \mathrm{H}_{0}$ : The achieved level of education of the respondents does not have a statistically significant effect on their work placement or their interest in further education.

$1 \mathrm{H}_{1}$ : The achieved level of education of the respondents has a statistically significant effect on their work placement and their interest in further education.

2. Set of hypotheses:

$2 \mathrm{H}_{0}$ : The approach towards employee placement based on their achieved qualification and towards further education is not different in micro, small, middle, or large companies.

$2 \mathrm{H}_{1}$ : The approach towards employee placement based on their achieved qualification and towards further education is different in micro, small, middle, and large companies.

3. Set of hypotheses:

$3 \mathrm{H}_{0}$ : The sector of the economy, in which the respondents work, does not have a statistically significant effect on their work placement or interest in further education.

$3 \mathrm{H}_{1}$ : The sector of the economy, in which the respondents work, has a statistically significant effect on their work placement or interest in further education.

4. Set of hypotheses:

$4 \mathrm{H}_{0}$ : The working position (manager/non-manager) does not have a statistically significant effect on their approach towards further education.

$4 \mathrm{H}_{1}$ : The working position (manager/non-manager) has a statistically significant effect on their approach towards further education.

\subsection{Methodology}

We used standard methods for scientific research such as analysis, synthesis, comparison, and selection, but a questionnaire survey was used as our major research method. The questionnaire survey was carried out in the period between December 2019 and December 2020 with a sample of 192 companies operating in Slovakia. The questionnaire was based on our research model and consisted (besides setting of the parameters P1, P2, P3, P4 Table 1) of four research indicators (VZ1, VZ2, VZ3, VZ4 - Table 2) focused on the work placement of the respondents based on their achieved qualification level and their approach towards further education with only one possible answer chosen from the alternatives. To evaluate the results, descriptive statistical methods and contingency tables were implemented and the hypotheses were verified using statistical methods and coefficients appropriate for evaluation of associations between nominal or dichotomic parameters: chisquare and Cramer's V [23]. For validation, PSPP statistical software was implemented.

\section{Results and Discussion}

The results are presented according to the following structure: the research sample and its parameters, evaluation of the indicators, and statistical verification of the hypotheses. 


\subsection{Research sample}

The research sample included 192 respondents who were grouped according to the following parameters $\mathrm{P} 1$ - achieved qualification before entering $1^{\text {st }}$ employment, P2 company size, P3 - sector of the economy, the company belongs to, P4 - current position (Table 1).

Table 1. Research sample parameters

\begin{tabular}{|l|l|c|c|}
\hline Parameter & Parameter Value & $\begin{array}{c}\text { Number of } \\
\text { Answers }\end{array}$ & \% of Incidence \\
\hline \multirow{2}{*}{$\begin{array}{l}\text { P1 - Achieved } \\
\text { qualification before } \\
\text { entering 1 }\end{array}$} & $\begin{array}{l}\text { st employment } \\
\text { examination }\end{array}$ & 46 & $23.96 \%$ \\
\cline { 2 - 4 } & tertiary & 146 & $76.04 \%$ \\
\hline \multirow{3}{*}{ P2 - Company size } & small (up to 49 employees) & 38 & $19.79 \%$ \\
\cline { 2 - 4 } & middle (50 to 249 employees) & 57 & $29.69 \%$ \\
\cline { 2 - 4 } & large (250+ employees) & 97 & $50.52 \%$ \\
\hline P3 - Sector of economy & primary & 36 & $18.75 \%$ \\
\cline { 2 - 4 } & secondary & 124 & $64.58 \%$ \\
\cline { 2 - 4 } & tertiary & 32 & $16.67 \%$ \\
\hline \multirow{2}{*}{ P1 - Current position } & manager & 81 & $57.81 \%$ \\
\cline { 2 - 4 } & non-manager & & $42.19 \%$ \\
\hline
\end{tabular}

Evaluation of the sample based on the parameters:

the sample consisted of $23.96 \%$ respondents with secondary education completed with a school-leaving examination and $76.04 \%$ respondents with tertiary education (P1).

As for the size of the companies (P2), the largest proportion belonged to large companies $(50.52 \%)$, then middle-sized companies (29.69\%), and lastly, small companies (including micro-sized ones) (19.79\%).

The third parameter (P3) divided the sample in the following way, $64.58 \%$ of respondents worked in the secondary sector (industry, construction, ...), $18.75 \%$ in the primary sector (agriculture, extraction of raw materials and minerals, ...) while the tertiary sector (various services) had the lowest representation (16.67\%).

The working position of the respondents (P4) was divided into $57.81 \%$ employees working in managerial positions and $42.19 \%$ occupying non-managerial positions.

We excluded from further processing all those values of the parameters which had $<5$ incidences.

\subsection{Evaluation of the indicators and their results}

The values of the indicators and their percentual incidence are presented in Table 2.

Table 2. Results of the evaluation of the studied indicators

\begin{tabular}{|l|l|c|c|}
\hline \multirow{2}{*}{ Indicator } & Indicator Value & $\begin{array}{l}\text { Number of } \\
\text { Answers }\end{array}$ & $\begin{array}{l}\text { \% of } \\
\text { Incidence }\end{array}$ \\
\hline \multirow{3}{*}{$\begin{array}{l}\text { VZ1 } \\
\text { Placement according } \\
\text { to qualification }\end{array}$} & yes & 145 & $75.52 \%$ \\
\cline { 2 - 4 } & no, one level above & 4 & $2.08 \%$ \\
\cline { 2 - 4 } & no, one level below & 23 & $11.98 \%$ \\
\cline { 2 - 4 } & a very different position & 20 & $10.42 \%$ \\
\hline
\end{tabular}




\begin{tabular}{|c|c|c|c|}
\hline \multirow{6}{*}{$\begin{array}{l}\text { VZ2 } \\
\text { Reasons for not being } \\
\text { placed according to } \\
\text { qualification }\end{array}$} & $\begin{array}{l}\text { there was no free position matching the } \\
\text { qualification }\end{array}$ & 24 & $12.50 \%$ \\
\hline & lack of knowledge, skills, and experience & 12 & $6.26 \%$ \\
\hline & $\begin{array}{l}\text { placement based on inheritance, privileges } \\
\text { etc. }\end{array}$ & 4 & $2.08 \%$ \\
\hline & influence of acquaintances & 4 & $2.08 \%$ \\
\hline & $\begin{array}{l}\text { discrepancy between qualification and } \\
\text { placement due to higher wage }\end{array}$ & 3 & $1.56 \%$ \\
\hline & not commented & 145 & $75.52 \%$ \\
\hline \multirow{2}{*}{$\begin{array}{l}\text { VZ3 } \\
\text { Employee's interest in } \\
\text { further training after } \\
\text { entering employment }\end{array}$} & yes & 150 & $78.13 \%$ \\
\hline & no & 42 & $21.88 \%$ \\
\hline \multirow{8}{*}{$\begin{array}{l}\text { VZ4 } \\
\text { Employee's target of } \\
\text { further training }\end{array}$} & $\begin{array}{l}\text { Development of knowledge and skills } \\
\text { within the field of study }\end{array}$ & 47 & $24.48 \%$ \\
\hline & $\begin{array}{l}\text { Development of knowledge and skills in } \\
\text { another field of study }\end{array}$ & 37 & $19.27 \%$ \\
\hline & $\begin{array}{l}\text { Development of knowledge and skills for a } \\
\text { managerial career }\end{array}$ & 18 & $9.38 \%$ \\
\hline & $\begin{array}{l}\text { Additional training for a specific type of } \\
\text { work }\end{array}$ & 31 & $16.15 \%$ \\
\hline & $\begin{array}{l}\text { Formal tertiary education - achieving } \\
\text { qualification }\end{array}$ & 25 & $13.02 \%$ \\
\hline & Acquiring key competences & 8 & $4.17 \%$ \\
\hline & $\begin{array}{l}\text { Self-study necessary for solving current } \\
\text { problems }\end{array}$ & 4 & $2.08 \%$ \\
\hline & No education & 22 & $11.46 \%$ \\
\hline
\end{tabular}

Based on the indicator values VZ1 (work placement according to qualification) we can state that the majority of respondents $(56.52 \%)$ were placed according to their qualification. Less than $24 \%$ of respondents were placed on a different level, out of which $11.98 \%$ below their qualification and $10.42 \%$ at a different post.

The main reason for not being placed according to their qualification was based on the answers, lack of free posts corresponding to their qualification (12.50\%). $6.26 \%$ admitted a lack of knowledge, skills, and experience.

$78.13 \%$ of respondents consider further education and training after entering employment (VZ3) important and expressed their interest in it but a relatively large part of respondents $(21.88 \%)$ is not interested. Despite that, approximately $10 \%$ of them chose one of the alternatives of indicator VZ4.

In terms of indicator VZ4, the highest proportion (24.48\%) expressed their interest in further development of their qualification, $19.27 \%$ is interested in other fields of study. The $10 \%$ threshold was passed by $16.15 \%$ who would prefer additional training for a specific type of work and $13.02 \%$ who would like to increase their qualification by formal tertiary education.

\subsection{Results of statistical validation}

The statistical validation of hypotheses was carried out based on the chi-square coefficient and Cramer's V. The results are summarised in Table 3, Table 4, Table 5, and Table 6. 
Table 3. Results of statistical validation of differences according to qualification (P1)

\begin{tabular}{|c|c|c|c|}
\hline Association & Chi square & df & Cramer's V \\
\hline VZ1/P1 & 1.41 & 3 & 0.09 \\
\hline VZ2/P1 & 2.84 & 4 & 0.25 \\
\hline VZ3/P1 & 0.74 & 1 & 0.06 \\
\hline VZ4/P1 & 3.46 & 7 & 0.13 \\
\hline
\end{tabular}

The results in Table 3 do not show statistical significance in any association. Therefore, we accept the $1 \mathrm{H}_{0}$ hypothesis and reject the $1 \mathrm{H}_{1}$ that is, we were not able to demonstrate any differences in the answers of respondents with secondary or tertiary education neither concerning their work placement or attitude towards further education.

Table 4. Results of statistical validation of differences according to company size (P2)

\begin{tabular}{|c|c|c|c|}
\hline Association & Chi square & df & Cramer's V \\
\hline VZ1/P2 & $14.79^{*}$ & 6 & 0.20 \\
\hline VZ2/P2 & $18.44^{*}$ & 8 & 0.44 \\
\hline VZ3/P2 & $3.98^{*}$ & 2 & 0.14 \\
\hline VZ4/P2 & $28.72^{*}$ & 14 & 0.27 \\
\hline${ }^{*} \mathrm{p}<0.05$
\end{tabular}

The data in Table 4 confirm a statistical significance in all indicators. Base on that, we reject the $2 \mathrm{H}_{0}$ hypothesis and accept the $2 \mathrm{H}_{1}$ hypothesis and state that both, the approach towards employee placement based on qualification and access to further training is different in micro, small, middle, and large companies.

Table 5. Results of statistical validation of differences according to the sector of the economy (P3)

\begin{tabular}{|c|c|c|c|}
\hline Association & Chi square & df & Cramer's V \\
\hline VZ1/P3 & 10.35 & 6 & 0.16 \\
\hline VZ2/P3 & 13.32 & 8 & 0.38 \\
\hline VZ3/P3 & 1.98 & 2 & 0.10 \\
\hline VZ4/P3 & $28.41^{*}$ & 14 & 0.27 \\
\hline
\end{tabular}

$* \mathrm{p}<0.05$

Table 6. Results of statistical validation of differences according to work position (P4)

\begin{tabular}{|c|c|c|c|}
\hline Association & Chi square & df & Cramer's V \\
\hline VZ1/P4 & 2.98 & 3 & 0.12 \\
\hline VZ2/P4 & 2.94 & 4 & 0.25 \\
\hline VZ3/P4 & $4.09^{*}$ & 1 & 0.15 \\
\hline VZ4/P4 & 6.44 & 7 & 0.18 \\
\hline${ }^{*} \mathrm{p}<0.05$
\end{tabular}

The results in Table 5 and Table 6 show statistical significance just in two cases (VZ4/P3 and VZ3/P4), therefore, in both cases the null hypotheses $3 \mathrm{H}_{0}$ and $4 \mathrm{H}_{0}$ are accepted and we rejected the alternative hypotheses $3 \mathrm{H}_{1}$ and $4 \mathrm{H}_{1}$. That means that we could not prove that either the sector of economy or the work post of the respondents has a statistically significant impact on their placement and interest in further education and training.

\section{Conclusion}

The main aim of the paper was to study the importance of the qualification achieved within the formal educational system on entering employment and the interest in and need for 
further education which would accompany the career development. Numerous individuals perceive career as equal to managerial post but interest in managerial training seems to be relatively low. Specialist training is much more preferred in companies operating in Slovakia. The most preferred is further training within the same field as the achieved qualification, and skills and knowledge specific for one's work position. We can state that interest in training in other fields is high due to the general requirement of interdisciplinarity. A great many attend different forms of formal education often accompanied by a change of qualification. We considered the start of a career essential for the placement of employees into positions according to their qualification and their interest in further professional training important for career development.

We discovered inadequacies in placing the employees according to their qualification; $3 / 4$ of the respondents were placed on posts according to their qualification but some $12 \%$ on lower positions. It is noteworthy that $11 \%$ were placed on posts requiring different qualification. It was caused by an inappropriate choice of field of study or by better remuneration system in other fields even in posts requiring a lower level of education.

The reasons for not placing the employees according to their qualification were lack of free posts and more than $6 \%$ mentioned inadequate knowledge, skills, and experience. Concerning the evaluation of graduates on entering their first employment by the employers, we can indicate that practical skills were considered more important than the acquired knowledge. Skill development is included in formal education only partially. Just a few fields of study at the secondary or tertiary level include practical training as part of the programme. The evaluations provided by employers pointed at further deficiencies in graduates' capacity of intuitive, creative, and strategic thinking. Meeting the requirements of employers is possible only if it is based on cooperation between educational institutions and companies.

$80 \%$ of respondents showed interest in further education within their field of study or some other but $20 \%$ were not interested. Further education is the reflection of aspirations, interests, and needs in building one's career. Though, part of those who are not interested in further education eventually participates in education as it is necessary to preserve their employment.

The statistical validation of the hypotheses confirmed two of our assumption. One is, that the size of a company is an important factor influencing our research topic - placement of employees and their approach towards further education. The other confirmed fact is that the sector of the economy does not influence it. The remaining two assumptions concerning the influence of the level of qualification and work post (manager/non-manager) were in our sample refuted.

The topic of education and career is quite extensive, and the paper could cover only part of our empirical research. We intend to continue the analysis of various aspects entering the decision-making process concerning the choice of education and career development. We would like to engage in the optimisation of educational choices utilising the services of educational and career councillors. Our ambition is also to increase the size of our sample.

\section{Acknowledgement}

The paper was elaborated within VEGA No. 1/0328/21 Post-pandemic business management: identifying temporary and sustainable changes in sequential and parallel management functions in the context of the COVID-19 pandemic - proportion $100 \%$. 


\section{References}

1. R. Bromber, The 60-Year Curriculum: New Models for Lifelong Learning in the Digital Economy. Distance Education 42, 1, 173-176 (2021)

2. I. Biao, Benin: Governance, lifelong learning and development. Journal of Adult and Continuing Education https://doi.org/10.1177/1477971421999411 (2021)

3. S. Dorian, N. Mirea, Lifelong Learning in Context of Industry 4.0. Acta Technica Napocensis - Series: Applied Mathematics, Mechanics, And Engineering 64, 1-S1, 55$62(2021)$

4. S. Cronholm, Lifelong Learning: Principles for Designing University Education. Journal of Information Technology Education: Research 35-60 (2021)

5. A. Tuckett, Europe's lifelong learning markets, governance and policy: Using an instruments approach. International Review Of Education 66, 5-6, 893-896 (2020).

6. B. Beláňová, Human Resources Policy in Relation to Cybernetic Security in Slovak Medium and Small Companies. In Current Problems of the Corporate Sector 2020. Paris, Édition Diffusion Presse Sciences, 1-10 (2020)

7. H. Lauder, The roles of higher education, further education and lifelong learning in the future economy. Journal of Education and Work 33, 7-8, 460-467 (2020)

8. M. Laal, P. Salamati, Lifelong learning; why do we need it? Procedia-Social and Behavioral Sciences 31, 399-403 (2012)

9. D. N. Aspin, J. D. Chapman, Lifelong learning: concepts and conceptions. International Journal of Lifelong Education 11, 19-38 (2007)

10. Ch. Wilding, Emoční inteligence: Vliv emocí na osobni a profesní úspěch. Praha, Grada Publishing (2010)

11. J. Suchý, P. Náhlovský, Pozitivní emoce: Jak je posilovat a rozvíjet v osobním $i$ pracovním životě. Praha, Grada Publishing (2012)

12. M. Flešková, V. Dolinská, Aplikovaná psychológia pre ekonómov a manažérov. Bratislava, Iura Edition (2010)

13. A. Slezáčková, Průvodce pozitivní psychologií. Praha, Grada Publishing (2012)

14. Z. Macková, Psychológia. Bratislava, Vydavatel'stvo Ekonóm (2012)

15. R. Kohoutek, The history and present in career counselling. http://rudolfkohoutek.blog.cz/1205/1 (2016)

16. M. Jigau, Kariérne poradenstvo: Kompendium metód a techník. http://web.saaic.sk (2011)

17. L. Beková, Š. Grajcár, D. Lepeňová, E. Uhríková, M. Zvariková. Kariérové poradenstvo v Slovenskej republike. Bratislava, Slovenská akademická asociácia pre medzinárodnú spoluprácu, centrum Euroguiance (2014)

18. M. Vaculík, Assessment centrum: Psychologie ve výběru a rozvoji lidí. Brno, NC Publishing (2010)

19. M. Daňková, Koučování. Kdy, jak a proč. Praha, Grada Publishing (2015)

20. Y. M. Kundi, S. Hollet-Haudebert, J. Peterson, Career adaptability, job crafting and subjective career success: the moderating roles of lone wolf personality and positive perfectionism. Personnel Review (2021)

21. R. F. Belchior, R. Lyons, Explaining entrepreneurial intentions, nascent entrepreneurial behavior and new business creation with social cognitive career theory-a 5-year 
longitudinal analysis. International Entrepreneurship and Management Journal 1-28 (2021)

22. M. Szarková, Reasons of Employees' Fluctuations from the Perspective of Employers in the Slovak Republic. In Hradec Economic Days 9, 404-413 (2019)

23. R. Hanák, Dátová analýza pre sociálne vedy. https://statistikapspp.sk/ucebnica/datovaanalyza-pre-socialne-vedy (2016) 